\title{
The study of the correspondence of marketing instruments to the stages of the start-up life cycle
}

\author{
Svetlana Nikiforova ${ }^{1, *}$ \\ ${ }^{1}$ St. Petersburg State University of Economics (UNECON), 21, Sadovaya street, 191023 St. \\ Petersburg, Russia
}

\begin{abstract}
The article is devoted to the results of an empirical study of the correspondence of market research methods and promotion tools to the stages of the life cycle of start-ups on the Russian market. The authors' model of the life cycle of the start-up, consisting of eight stages, is grounded. The authors present the results of an empirical study, consisting of expert interviews and a quantitative survey. A model for the correspondence of marketing instruments to the stages of the life cycle of a start-up is compiled. It is proved that in the process of development of a start-up, the number of marketing instruments used (especially digital tools) should increase at every stage of its life cycle. Based on the results of a desk and empirical studies, a system of criteria and a tool for assessing the sustainable development of a startup at various stages of its life cycle are proposed.
\end{abstract}

\section{Introduction and Literature Overview}

Trends in the development of the economy of any modern country are continuously linked to the notions of innovation and innovative development. The basis for the development of innovative economy are innovative enterprises of various forms of ownership and methods of organization. Startups play a special role among such enterprises. Startup is a temporary structure that unites people pursuing a common goal the development and rapid implementation of a viable innovative idea in the form of a profitable mass product or service. Startups are the most flexible market participants who increase the rate of innovation development of the economy, introduce new ideas and modernize the existing development base. Startups are entities that operate in an environment of extreme disinclination, therefore, in order to activate their potential and commercialize innovations, they desperately need marketing support for their activities.

Marketing instruments that support the activities of a start-up should be carried out in relation to the stages of its life cycle. The life cycle of the start-up is shorter than the "traditional" life cycle of the company and even the product, but it includes certain specific stages. The authors analyzed the most popular approaches to constructing a model and determining the stages of the life cycle of a start-up (by E.Ries, S.Blank, B.Dorf, P.Graham,

\footnotetext{
*Corresponding author: sergiiblack@mail.ru
} 
F.Kotler, I.Adizes, R.Fiyaksel, A.Parabellum, D.Zapirkin and many others $[1,3,5,7,8$, $10])$. The results of the analysis show that researchers consider two types of life cycle of a startup: for the company and for the product. At the same time, the modern market of marketing operations for start-ups does not divide these two concepts. For a start-up, the development of the company is continuously linked and unambiguously determined by the development of its main product, which in turn must take into account the possibility of carrying out corrective measures and return to the previous stages (which is absent, for example, in F.Kotler's model). All authors offer their own vision of the structure of the life cycle of a start-up, based on the research goals and fields of start-up activity, which lead to the conclusion that the life cycle of a startup can be divided differently.

Based on the analysis and generalization of the publications of the authors who made the greatest contribution to the development of the theory of start-ups, and also taking into account the conducted desk-based research of the practice of functioning of start-ups from different countries, the authors formulate their own concept of the life cycle of a start-up as a symbiosis of the life cycle of a product and company, taking into account the specificity of speed development and launch of the start-up. The approaches proposed by F.Kotler and I.Adizes (which are well suited for the first half of the life cycle of a start-up and determine the development of an idea before entering the market) were used as the form factors, in combination with the approaches of E.Ries, A.Parabellum and D.Zapirkin for the 2nd half of the life cycle of a start-up (who focus on the necessary possibility of conducting corrective actions at any stage) (see Figure 1).

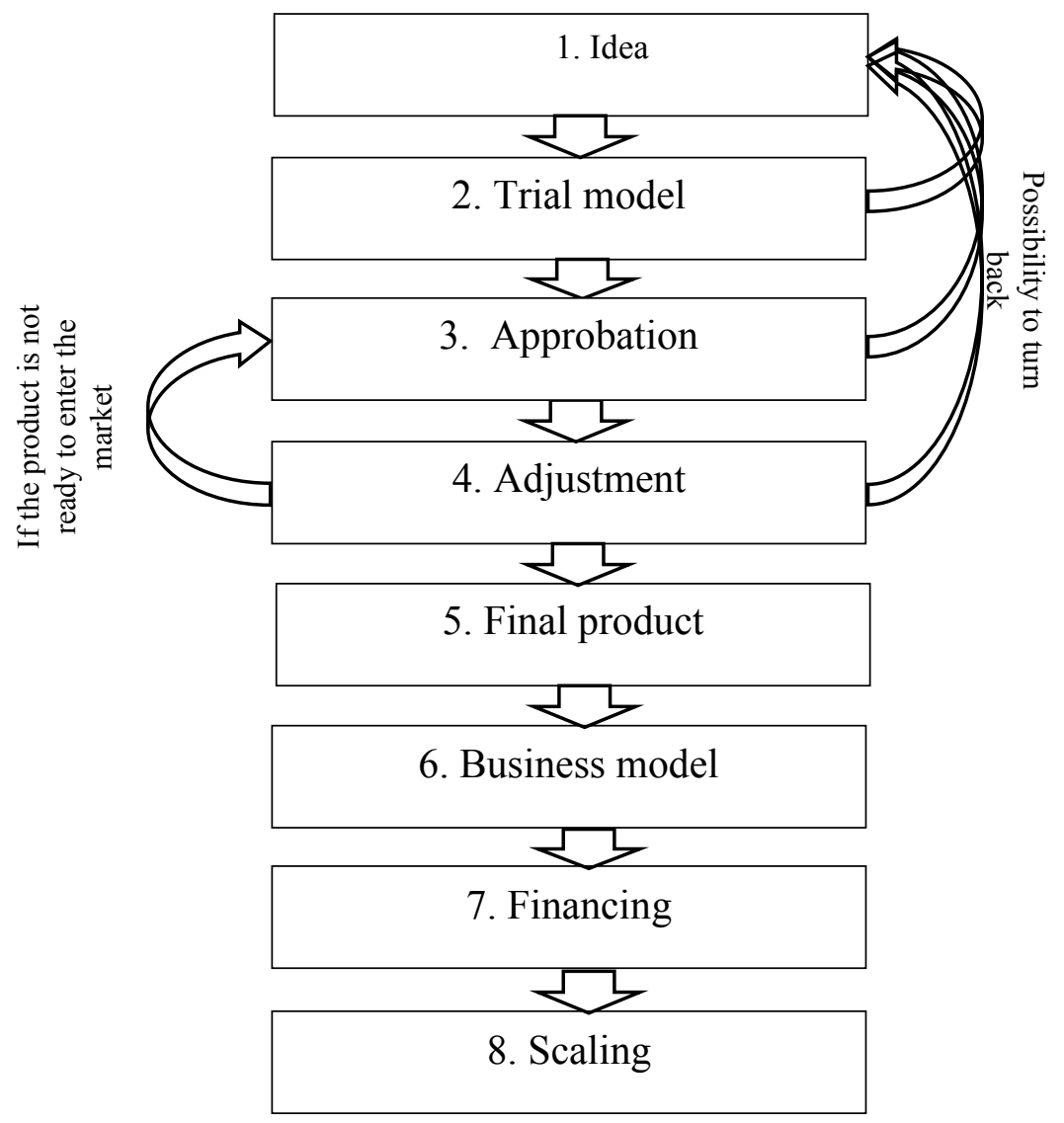

Fig. 1. Authors' concept of the life cycle of a start-up. 
The authors believe that eight stages of the start-up life cycle, presented in Figure 1, should be distinguished from the difference in the directions of investment and the main goal of marketing activities, however, in terms of the "proximity" of the product / service to the end user, eight stages of the start-up life cycle can be combined in four enlarged stages: first enlarged stage "Concept" (the goods exist only in the form of an idea and a primary prototype), second enlarged stage "Test" (the product in its first version is put on the market), third enlarged stage "Working out" (the results of the previous stage are fully corrected, all the points of creating and promoting the final product / service are worked out), fourth enlarged stage "Launch" (search for investors and large-scale launch of the start-up on the market).

\section{Research methodology and Data analysis}

The distribution of marketing instruments between the stages of the life cycle of a start-up should be based on the results of not only a desk study, but also an empirical one. That's why the authors conducted an empirical study of the effectiveness of start-ups development in the Russian market. The main aim of the empirical research was to determine the degree of influence of modern marketing instruments on the development of a start-up considering the theory of the start-up life cycle. The following hypotheses of empirical research were formulated (see Table 1).

Table 1. Hypotheses of empirical research.

\begin{tabular}{|c|}
\hline $\begin{array}{c}\text { Hypothesis 1: Marketing activities are a key component of the effective development of a start- } \\
\text { up in the modern market. }\end{array}$ \\
\hline $\begin{array}{c}\text { Hypothesis 2: The used marketing instruments (including market research methods and } \\
\text { promotion tools) depend on the stage of the start-up life cycle. }\end{array}$ \\
\hline $\begin{array}{c}\text { Hypothesis 3: Digital marketing tools are the most significant modern marketing tools for } \\
\text { promoting a start-up. }\end{array}$ \\
\hline Hypothesis 4: Digital marketing tools are not significant at the first stages of the start-up \\
development \\
\hline $\begin{array}{c}\text { Hypothesis 5: The most important tools of digital marketing for start-ups are mobile } \\
\text { marketing, SEO, SMM, banners. The least important are contextual advertising, blogs, viral } \\
\text { advertising. }\end{array}$ \\
\hline
\end{tabular}

To develop the research methodology, the authors conducted preliminary structured interviews with 11 specialists in the field of start-up development: professional marketers (5), leaders of successful Russian start-up companies (3), and experts in the field of start-up development in the modern Russian market (3 professors). Interviews were held in the period of May-September 2016. The interviews allowed to determine the main areas of future research, to formulate basic hypotheses, questions, possible ranges of answers to them. So, the interviews allowed to finally approve the logic and methodology of the study, as well as to develop a questionnaire.

The next stage of the empirical research was a quantitative study, which consisted of a survey of 162 respondents related to start-ups from such industries as medical equipment and pharmaceuticals, space technology and telecommunications, computer technologies and programs, energy efficiency and resource saving.

The sample consisted of representatives of start-ups, corresponding to the following criteria: the period of organization functioning is less than 3 years (E.Ries [8]); income level is at least $\$ 1$ million [6]; the speed of entry to the market is rather high [9]; innovation as a base of start-up can be not only technological, but also marketing or management (P.Graham, R.Fiaksel [3, 4]); business model of the organization is 
reproducible, easy scalable, profitable and has great growth potential (S. Blank and B. Dorf [1]).

Quantitative research was conducted using the Internet survey method through docs.google.com in September-December 2016. The number of questionnaires sent was 200 , the return rate was $81 \%$.

The author's questionnaire consisted of three blocks:

BLOCK 1 - General issues related to the scope of the startup, its age and life cycle stage;

BLOCK 2 - Special questions regarding the role of marketing in the company;

BLOCK 3 - Specialized questions concerning the appropriateness of using different marketing instruments at different stages of the start-up life cycle [11].

To analyze the results of the research, methods of frequency, correlation-

regression, factor, and cluster analysis were used in MS Excel.

The conducted cluster analysis showed that the stages of the start-up life cycle identified by the authors can be grouped into three clusters according to the level of implementation of marketing activities. Their intensity should increase when the product is switched to the stage of Finished product (according to the authors' concept of the life cycle of a start-up) after the Adjustment based on the results of the Approbation, and also after the development of the Business model at the beginning of its Financing.

Frequency analysis helped to identify the most frequently used marketing tools, depending on the stage of the start-up life cycle. Since in the relatively large part of the stages more than $50 \%$ of respondents were unanimous in determining the most significant marketing instrument, it can be concluded that the choice of the marketing instrument directly affects the development of the start-up.

One-dimensional factor analysis made it possible to identify some of the most significant marketing tools and it turned out that they are the tools of digital marketing, among which SMM, Landing Pages, Email-marketing and web analytics play a special role. In accordance with the factor and frequency analysis, an invariant was defined in which the distribution of marketing instruments is maximized at each individual stage of the start-up life cycle (see Table 2).

Table 2. The correspondence of marketing instruments to the stages of the life cycle of a start-up (based on the results of empirical study).

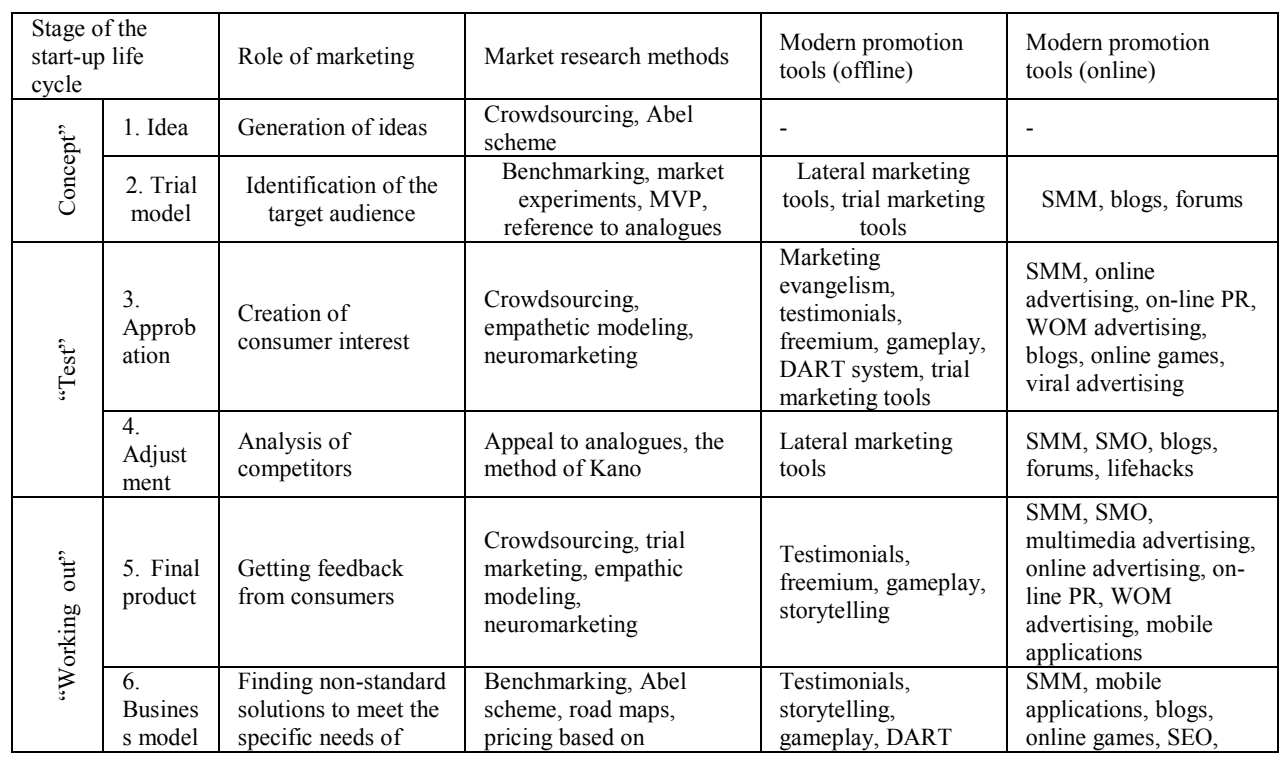




\begin{tabular}{|l|l|l|l|l|l|}
\hline & consumers & $\begin{array}{l}\text { perceived value, market } \\
\text { map }\end{array}$ & system & viral advertising \\
\hline & $\begin{array}{l}7 . \\
\text { Financi } \\
\text { ng }\end{array}$ & $\begin{array}{l}\text { Full analysis of the } \\
\text { functional purpose of } \\
\text { the product and its } \\
\text { target audience }\end{array}$ & $\begin{array}{l}\text { Road (strategic) maps, } \\
\text { benchmarking, market } \\
\text { map }\end{array}$ & $\begin{array}{l}\text { Viral marketing, } \\
\text { marketing } \\
\text { evangelism, DART } \\
\text { system }\end{array}$ & $\begin{array}{l}\text { Contextual advertising, } \\
\text { SEO, viral advertising }\end{array}$ \\
\cline { 2 - 6 } & $\begin{array}{l}\text { Carrying out the } \\
\text { final adjustment of } \\
\text { the marketing } \\
\text { strategy and making } \\
\text { marketing plans }\end{array}$ & $\begin{array}{l}\text { Benchmarking, Abel } \\
\text { scheme, neuromarketing }\end{array}$ & $\begin{array}{l}\text { Viral advertising, } \\
\text { testimonials, } \\
\text { freemium, } \\
\text { storytelling, } \\
\text { gameplay }\end{array}$ & $\begin{array}{l}\text { SMM, SMO, } \\
\text { advertising in } \\
\text { multimedia, online } \\
\text { advertising, on-line PR, } \\
\text { WOM advertising, } \\
\text { mobile applications, } \\
\text { blogs, on-line games, } \\
\text { SEO }\end{array}$ \\
\hline
\end{tabular}

Correlation-regression analysis showed that during the evolution of the start-up (the start-up movement through the life cycle stages), the number of marketing instruments used is steadily increasing ( $\mathrm{R} 2=81 \%$, see Fig. 2). For digital marketing tools, this trend is even more characteristic (R2 $=92 \%$, see Fig. 3$)$.

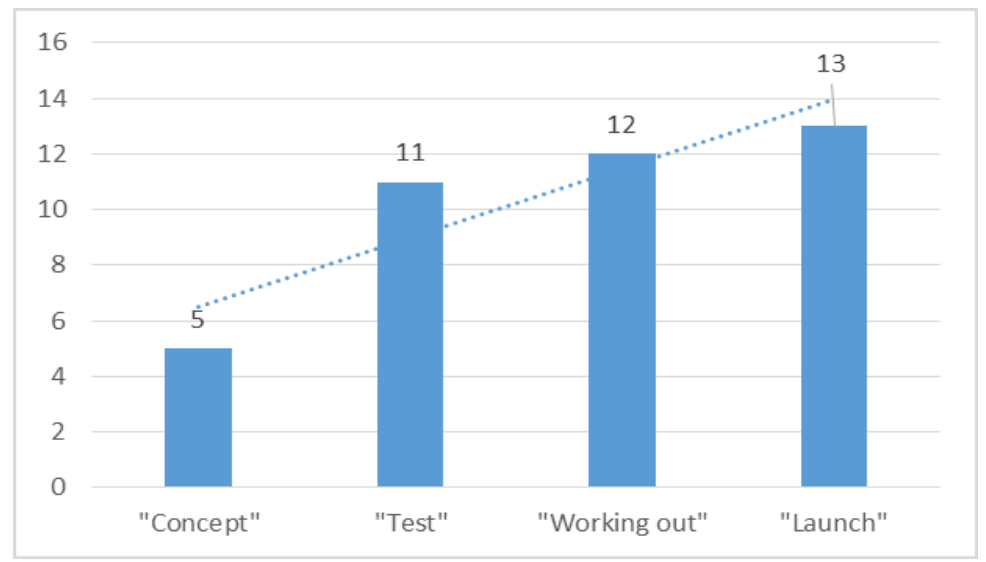

Fig. 2. Distribution of the number of marketing instruments used depending on the stage of the startup life cycle.

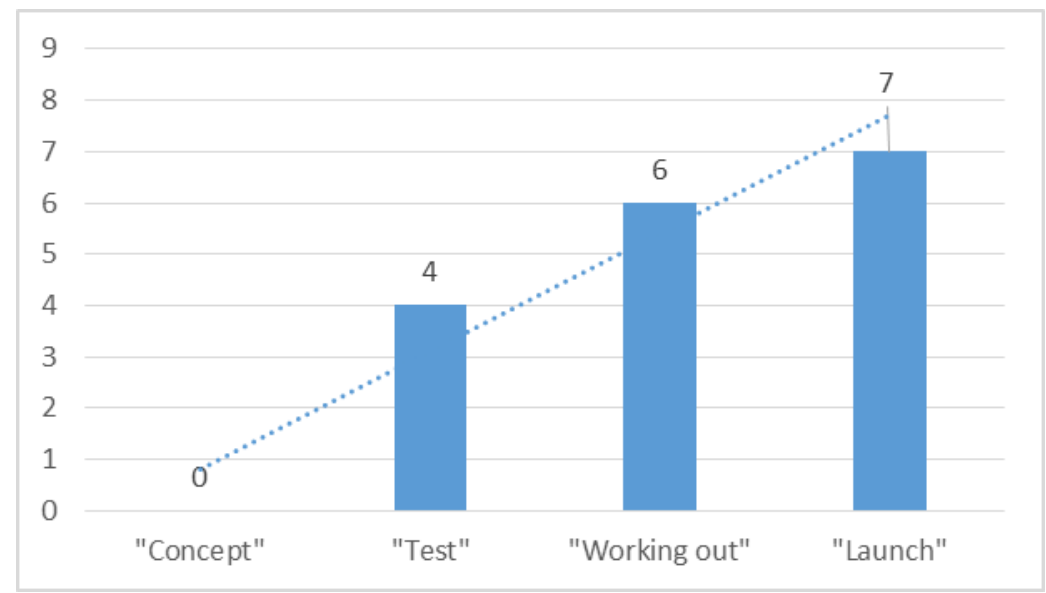

Fig. 3. Distribution of the number of digital marketing tools used depending on the stage of the startup life cycle.

Based on the results of the questionnaire, hypotheses of the empirical research were confirmed or partly confirmed (see Table 3 ). 
Table 3. Hypothesis confirmation.

\begin{tabular}{|c|c|}
\hline $\begin{array}{c}\text { Hypothesis 1: Marketing activities are a key component of the effective } \\
\text { development of a start-up in the modern market. }\end{array}$ & Confirmed \\
\hline $\begin{array}{c}\text { Hypothesis 2: The used marketing instruments (including market research } \\
\text { methods and promotion tools) depend on the stage of the start-up life cycle. }\end{array}$ & $\begin{array}{c}\text { Confirmed } \\
\text { (R2=81\%) }\end{array}$ \\
\hline $\begin{array}{c}\text { Hypothesis 3: Digital marketing tools are the most significant modern } \\
\text { marketing tools for promoting a start-up. }\end{array}$ & Confirmed \\
the start-up development & Partly confirmed \\
\hline $\begin{array}{c}\text { Hypothesis 4: Digital marketing tools are not significant at the first stages of } \\
\text { mobile marketing, SEO, SMM, banners. The least important are contextual } \\
\text { advertising, blogs, viral advertising. }\end{array}$ & $\begin{array}{c}\text { Confirmed } \\
\text { (R2=92\%) }\end{array}$ \\
\hline $\begin{array}{c}\text { Hypothesis 1: Marketing activities are a key component of the effective } \\
\text { development of a start-up in the modern market. }\end{array}$ & Partly confirmed \\
\hline
\end{tabular}

\section{Discussion}

Based on the results of the theoretical and empirical study, authors substantiated eight marketing criteria for evaluating the sustainable development of the start-up:

- Number of marketing tools used;

- Number of digital marketing tools used;

- Share of marketing expenses;

- Share of expenses for digital marketing in total marketing expenses;

- Share of own capital in the structure of marketing investments;

- Number of marketing functions implemented;

- Duration of the life cycle stage (in months);

- Increase in the number of queries in search engines and social networks, according to the keywords associated with the start-up.

On the basis of this system of criteria, the authors created a marketing tool for assessing the sustainable development of a start-up, which is presented by the profiles of the optimal criteria values that are unique for each stage of the start-up life cycle. The optimal values of the criteria are the ones that allow to assess the current state of the start-up as sustainable and to ensure this sustainability in future periods (at the next stages of the start-up life cycle), which is reflected in the preservation of investment attractiveness for various categories of investors throughout the life cycle of a start-up [2, 4, 6, 9]. The minimum, maximum, and the range of optimal values of these criteria were determined during the desk-based and empirical studies. Minimum and maximum values are the same for all stages of the start-up life cycle, while the range of optimal values is different. Construction of the real profile of a start-up and its correlation with the recommended one allows to determine the degree of sustainability of the start-up development and, in case of deviations, to formulate recommendations for changing this trend.

Table 4 presents an example of the optimal values of the criteria for the sustainable development of a start-up at the enlarged stage of its life cycle "Concept" (according to the authors' concept of the life cycle of a start-up, shown in Figure 1).

The main aim of the first enlarged stage of start-up development is to determine the market segment on which the start-up will function, with the subsequent formation of the overall vision of the start-up existence. In the process, a fairly limited set of marketing functions is implemented: analytical and, in part, strategic [12-15]. The analytic function is necessary and sufficient. As the study showed, this set of marketing functions is provided by 5 promotion tools and methods of market research which are traditional ones. Of course, the addition of digital tools is acceptable, but in order to optimize the marketing budget, this 
addition should not exceed $20 \%$ of the set value. Since this stage of the life cycle is the first, and within it only borrowed capital is attracted, the share of own capital in the structure of marketing investments prevails.

Table 4. Optimal values of the criteria for sustainable start-up development at the enlarged stage of the start-up life cycle "Concept".

\begin{tabular}{|c|c|c|c|c|}
\hline \multirow[t]{13}{*}{ «Concept» } & \multicolumn{4}{|c|}{ Enlarged stage of a start-up life cycle } \\
\hline & \multicolumn{2}{|c|}{$\begin{array}{c}\text { Number of marketing tools } \\
\text { used (A) }\end{array}$} & \multicolumn{2}{|c|}{$\begin{array}{c}\text { Share of own capital in the structure of } \\
\text { marketing investments (E) }\end{array}$} \\
\hline & MIN & MAX & MIN & MAX \\
\hline & $5(0,24)$ & $6(0,29)$ & $50(0,5)$ & $80(0,8)$ \\
\hline & \multicolumn{2}{|c|}{$\begin{array}{l}\text { Number of digital marketing } \\
\text { tools used (B) }\end{array}$} & \multicolumn{2}{|c|}{$\begin{array}{l}\text { Number of marketing functions } \\
\text { implemented (F) }\end{array}$} \\
\hline & MIN & MAX & MIN & MAX \\
\hline & $0(0)$ & $1(0,14)$ & $1(0,13)$ & $2(0,25)$ \\
\hline & \multicolumn{2}{|c|}{$\begin{array}{l}\text { Share of marketing expenses } \\
\text { (C) }\end{array}$} & \multicolumn{2}{|c|}{$\begin{array}{l}\text { Duration of the life cycle stage (in } \\
\text { months) }(\mathrm{G})\end{array}$} \\
\hline & MIN & MAX & MIN & MAX \\
\hline & $15(0,15)$ & $30(0,30)$ & $1(0,08)$ & $3(0,25)$ \\
\hline & \multicolumn{2}{|c|}{$\begin{array}{l}\text { Share of expenses for digital } \\
\text { marketing in total marketing } \\
\text { expenses (D) }\end{array}$} & \multicolumn{2}{|c|}{$\begin{array}{l}\text { Increase in the number of queries in } \\
\text { search engines and social networks, } \\
\text { according to the keywords associated } \\
\text { with the start-up }(\mathrm{H})\end{array}$} \\
\hline & MIN & MAX & MIN & MAX \\
\hline & $0(0)$ & $10(0,10)$ & $0(0)$ & $0(0)$ \\
\hline
\end{tabular}

The share of marketing expenses is relatively small, due to the set of marketing functions being implemented. The duration of this stage largely depends on the industry specifics of the start-up, however, according to the conducted research (expert interviews), its duration should not exceed 3 months due to the speed of scientific and technological progress and the dynamics of interest rates on borrowed capital. The increase in the number of queries in search engines and social networks, by keywords associated with the startup, is invariably zero, since this stage is the basis for calculating this indicator.

\section{Conclusion}

Due to the fact that the criteria are determined in different units of measurement, the ratio of the optimum and the maximum allowable values was chosen as the unified unit of comparison (these ratios are indicated in parentheses in Table 4). Figure 4 shows the optimal profile of sustainable development for the enlarged stage of the life cycle of a startup "Concept". The boundaries of the optimal values within this profile are uneven. In particular, with a much larger share of own capital in the structure of marketing investments, the maximum values of the remaining criteria are much lower. This stage of the life cycle is the most ambiguous from the marketing point of view. Its key specificity is the comprehensive application of the analytical function of marketing. Neglect of this function will inevitably lead to negative economic results at the subsequent stages of the start-up life cycle. 


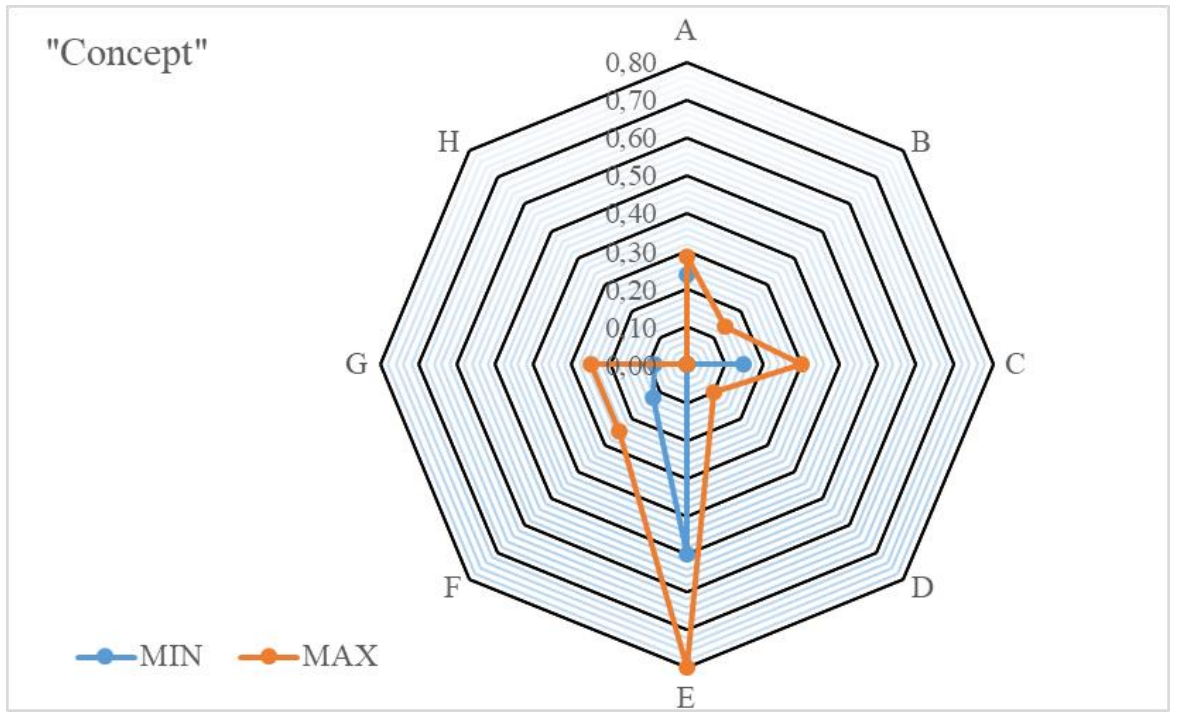

Fig. 4. Optimal profile of the sustainability of the start-up development in the "Concept" enlarged stage of the start-up lifecycle.

Continuation of building the profiles of sustainable development of the start-up at the subsequent stages of its life cycle forms the marketing tool proposed by the authors to assess the sustainable development of the start-up. The use of this tool is aimed at ensuring the sustainability of the start-up in the current period, while creating a stable basis for subsequent periods of its life cycle.

\section{References}

1. S. Blank, B. Dorf, The Startup Owner's Manual: The Step-By-Step Guide for Building a Great Company (2014)

2. D.S. Demidenko, A.M. Malinin, A.N. Litvinenko, Proceedings of the 30th International Business Information Management Association Conference, IBIMA 2017 - Vision 2020: Sustainable Economic development, Innovation Management, and Global Growth, 3017-3021 (2017)

3. R.E. Fiyaksel, Ekonomika I upravlenie 8, $43-48$ (2011)

4. Y. Klochkov, A. Gazizulina, N. Golovin, Proceedings - 2nd International Symposium on Stochastic Models in Reliability Engineering, Life Science, and Operations Management, SMRLO 2016, 530-532 (2016)

5. F. Kotler, Marketing Essentials (2018)

6. T.J. Kudryavtseva, E.A. Ivanova, E.A. Kozlova, A.E. Skhvediani, Academy of Strategic Management Journal 16(1), 110-122 (2017)

7. A. Parabellum, D. Zapirkin, Business development. Your success is your decision (Publishing house Phoenix, 2012)

8. E. Ries, The Lean Startup: How Today's Entrepreneurs Use Continuous Innovation to Create Radically Successful Businesses (Crown Business, 2011)

9. D.G. Rodionov, I.A. Rudskaia, V.A. Degtereva, Proceedings of the 29th International Business Information Management Association Conference, Education Excellence and 
Innovation Management through Vision 2020: From Regional Development Sustainability to Global Economic Growth, 3437-3450 (2017)

10. A.S. Sokolitsyn, M.V. Ivanov, N.A. Sokolitsyna, Proceedings of the 30th International Business Information Management Association Conference, IBIMA 2017, Vision 2020: Sustainable Economic development, Innovation Management, and Global Growth, 1053 - 1063 (2017)

11. S.V. Sovershaeva, Evaluation of the effectiveness of digital marketing communications, PHd thesis (SPB, 2014)

12. S. Chernyi, V. Budnik, Methods for optimizing solutions when considering group arguments by team of experts (2017) DOI: 10.1063/1.5009873

13. S. Sokolov, A. Zhilenkov, S. Chernyi, A. Nyrkov, Procedia Computer Science 125, 420-426 (2018)

14. A. Nyrkov, A. Shnurenko, S. Sokolov, S. Chernyi, V. Korotkov, Procedia Engineering, 178, 543-550 (2017)

15. S. Chernyi, Methods for ensuring fault tolerance of equipment based on reliability theory, 2018 IEEE Conference of Russian Young Researchers in Electrical and Electronic Engineering (EIConRus) (2018) 